\title{
A Reverse Dynamical Investigation of the Catastrophic Wood- Snow Avalanche of 18 January 2017 at Rigopiano, Gran Sasso National Park, Italy
}

\author{
Barbara Frigo $^{1}$ - Perry Bartelt ${ }^{2} \cdot$ Bernardino Chiaia $^{1} \cdot$ Igor Chiambretti $^{3}$. \\ Margherita Maggioni ${ }^{4,5}$
}

Accepted: 2 June 2020/Published online: 20 November 2020

(C) The Author(s) 2020

\begin{abstract}
On 18 January 2017 a catastrophic avalanche destroyed the Rigopiano Gran Sasso Resort \& Wellness (Rigopiano Hotel) in the Gran Sasso National Park in Italy, with 40 people trapped and a death toll of 29. This article describes the location of the disaster and the general meteorological scenario, with field investigations to provide insight on the avalanche dynamics and its interaction with the hotel buildings. The data gathered in situ suggest that the avalanche was a fluidized dry snow avalanche, which entrained a sligthtly warmer snow cover along the path and reached extremely long runout distances with braking effect from mountain forests. The avalanche that reached the Rigopiano area was a "wood-snow" avalanche-a mixture of snow and uprooted and crushed trees, rocks, and other debris. There were no direct eyewitnesses at the event, and a quick post-event survey used a numerical model to analyze the dynamics of the event to estimate the pressure, velocity, and direction of the natural flow and the causes for the destruction of the hotel.
\end{abstract}

Barbara Frigo

barbara.frigo@polito.it

1 Department of Structural, Building and Geotechnical Engineering - DISEG, Politecnico di Torino, 10129 Turin, Italy

2 WSL Institute for Snow and Avalanche Research SLF, 7260 Davos Dorf, Switzerland

3 Associazione Interregionale di Coordinamento e documentazione per i problemi inerenti alla Neve e alle Valanghe - AINEVA, 38122 Trento, Italy

4 Dipartimento di Scienze Agrarie, Università di Torino, Forestali e Alimentari - DISAFA, 10095 Grugliasco, TO, Italy

5 Centro Interdipartimentale sui Rischi Naturali in Ambiente Montano e Collinare - NatRisk, 10095 Grugliasco, TO, Italy
Considering the magnitude and the damage caused by the event, the avalanche was at a high to very high intensity scale.

Keywords Avalanche flow velocity - Avalanche impact pressure $\cdot$ Forensic field investigation · Italy $\cdot$ Rigopiano disaster . Wood-snow avalanche

\section{Introduction}

The snow emergencies that occurred in Central and South Italy in mid-January 2017 are well known to the experts. The most critical situations occurred in the Marche, Abruzzo, and Molise regions where the recorded snow accumulations were extreme: starting from the altitude of 800-900 $\mathrm{m}$ above sea level (asl), the snowpack easily exceeded 300-350 cm. Dramatic emergencies occurred: difficulties in road clearing, absence of electricity for days (more than 100,000 users were left without electricity for almost a week), isolated houses and villages due to the thick snowpack, and so on. The social and economic costs of the snow event in the central Apennines were very high, even without considering the Rigopiano tragedy.

On 18 January 2017, seismic events occurred in the morning: they were distinctly felt at the Rigopiano Gran Sasso Resort \& Wellness (abbreviated as "Rigopiano Hotel"), spreading panic among the residents. But, due to the severe weather conditions, the 9-km long access road (provincial road no. 8) to the hotel was blocked by fresh snow, and power supply and telecommunication were interrupted. None of the entrapped 11 employees and 29 guests had any chance of either receiving help from outside or of leaving the hotel after the seismic shocks. 
At about 15:40 (UTC), from an open slope on the east aspect of Mt. Siella at $1969 \mathrm{~m}$ asl-Gran Sasso Massif, Italy, latitude 42.430992, longitude 13.782408-a snow avalanche released, immediately encountered the beech forest and increased its mass by entraining the trees in the snow flow, running down the 2-km long natural channel, then impacted the Rigopiano Hotel (at about $1118 \mathrm{~m}$ asl) at a terrific pressure/velocity and destroyed the reinforced concrete structure. The consequences were catastrophic: the avalanche displaced the building downhill by almost $50 \mathrm{~m}$, tearing the concrete columns, tilting the upper floors and the roof, and killing 29 people. The Rigopiano avalanche was the most significant tragedy caused by a snow avalanche since the 1916 White Friday Mount Marmolada event (Brugnara et al. 2017) in Italy, and since the string of 1999 avalanches in Europe-Galtur, Austria (Höller 2009); Montroc, France (Rapin and Ancey 2000); and Tacconaz, France (Berthet-Rambaud et al. 2007), by the number of deaths due to the avalanche impacts on buildings.

The forensic investigation started only 9 days later, on 27 January 2017, because in the days before the priority was to complete the problematic rescue operations aimed at finding possible survivors trapped under the debris of the building. The search and rescue operations lasted from the early morning of 19 January until the afternoon of 27 January and employed, on average, 347 rescuers and technicians, and several dozens of types of machinery that were used to remove the debris and open up spaces for the rescuers.

Fig. 1 Aerial view of the avalanche path above Rigopiano Hotel before (2015) and after (2017) the catastrophic avalanche event that occurred on 18 January 2017 in Farindola, Pescara, Italy. Source Google Earth
One of the main activities of the forensic investigation, in which three of the authors participated, aimed at reconstructing the most likely dynamics of this remarkable avalanche event, to interpret and determine the causes of the failure of the hotel. The Rigopiano avalanche was a "wood-snow" avalanche-a mixture of snow, uprooted and crushed trees, rocks, and debris, but at the same time presented many typical features of a fast dry-flowing avalanche. These include snow entrainment and long runout distances, with only little damping and slowing effect provided by the mountain forests.

Here, the main aspects of the investigation are briefly reported, and the numerical simulation of the avalanche that was carried out with the software RAMMS (developed by the Swiss Federal Institute for the Study of Snow and Avalanches-Davos (CH)) is described. This article presents how the flow dynamic of the event and the subsequent impact to the hotel were reconstructed with the in situ observations and the results of the avalanche model. The numerical model simulates the most likely flow dynamics according to the principles of reverse engineering analysis - the simulations helped to understand the causes of the terrific structural collapse of the hotel.

\section{Location of the Avalanche Disaster}

Rigopiano in the Municipality of Farindola, Pescara, Italy is located on the northeast slopes of the Gran Sasso d'Italia massif, in a relatively flat and open sector of the eastern

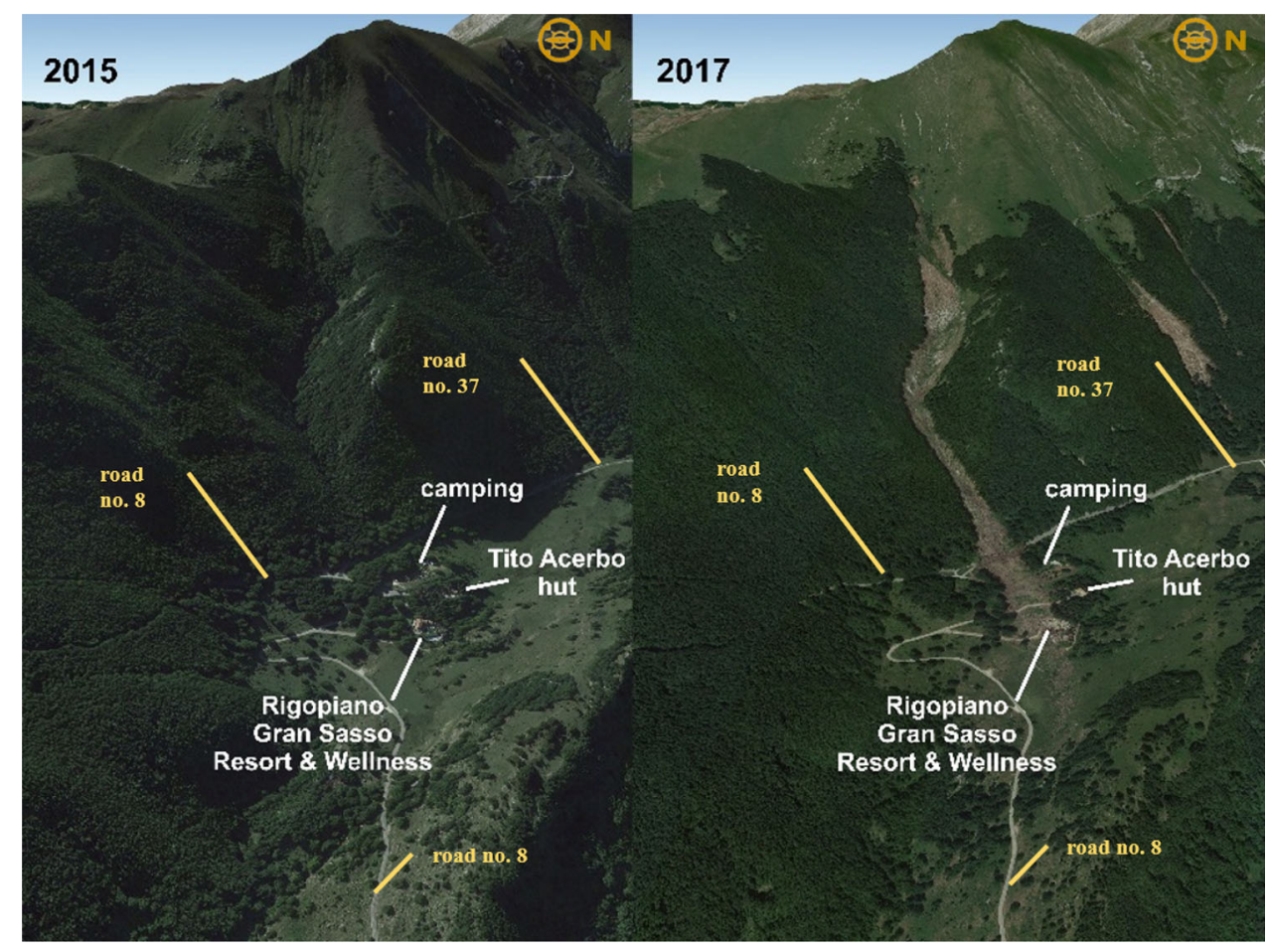


(a)

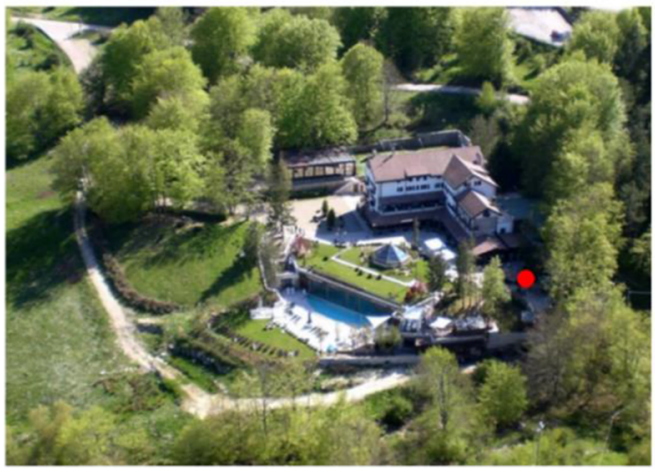

(b)

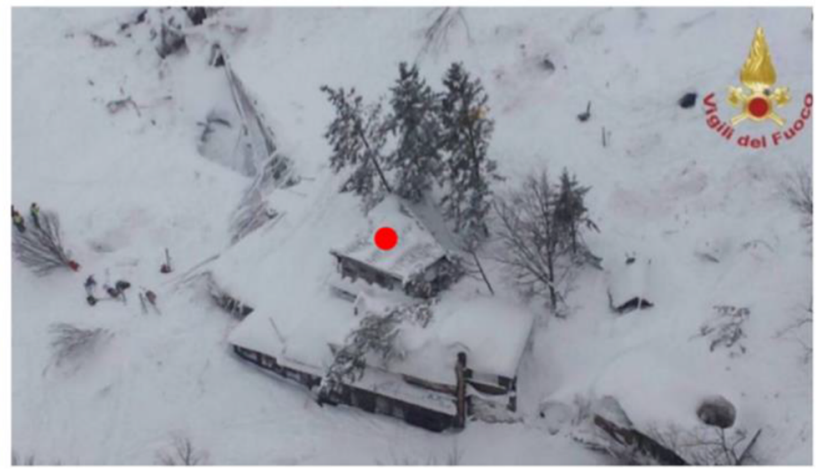

Fig. 2 Aerial view of the Rigopiano Hotel before (a) and after (b) the avalanche that occurred on 18 January 2017 in Farindola, Pescara, Italy. The red dot indicates a part of the hotel that was damaged, but not razed by the avalanche. Source a https://www.adnkronos.com/ fatti/cronaca/2017/01/19/lusso-spa-ecco-com-era-hotel-rigopiano_

slopes of Mt. Siella (2027 m asl), at $1118 \mathrm{~m}$ asl. It is located near the intersection of provincial roads no. 8 and no. 37, the latter built in the 1950s to connect the eastern side of the Gran Sasso Massif (Pescara) with the western side (L'Aquila) (Fig. 1).

Less than $100 \mathrm{~m}$ from the hotel, in northeast direction, lies the Tito Acerbo mountain hut, and in the north direction, there was an equipped campground that was razed by the avalanche. The campground occupied an area of about $20,650 \mathrm{~m}^{2}$ with pitches for caravans, spaces for tents, green and picnic areas, and in the northwest section toilets built totally underground and made in reinforced concrete. Dating from the 1930s and recently renovated, the Tito Acerbo shelter has a rectangular shape (about $17 \mathrm{~m} \times 14.5 \mathrm{~m}$ ), with two floors aboveground. Both facilities were closed in January 2017.

\subsection{The Rigopiano Hotel Structure}

Located in one of the most beautiful sites of Abruzzo, the Rigopiano Hotel was a 4-star hotel. In the heart of the Gran Sasso National Park, with a view of the Adriatic Sea, the hotel stood at $1118 \mathrm{~m}$ asl, with a $1200 \mathrm{~m}^{2}$ surface area, subdivided into 43 rooms, bar, congress center, "Il Vate" restaurant, and a $1300 \mathrm{~m}^{2}$ wellness center and outdoor/indoor pool. The hotel grounds, arranged in a radial design, primarily included three communicating sections: the 4-level main structure, the lower structure attached to it (with three aboveground floors) including the original nucleus, and the underground area, devoted to the wellness center (Fig. 2).

The original nucleus was a simple mountain hut, built just below and after the Tito Acerbo shelter (built by the
GXquCklRmlDNX8pYaXO3qI.html?refresh_ce (Facebook/Gran Sasso Spa \& Beauty Hotel Rigopiano). b https://www.corriere.it/fotogallery/cronache/17_gennaio_19/hotel-rigopiano-slavina-soccorsi-gal lery-6d595074-de17-11e6-93cd-d08bed2f6059.shtml

Forestry Militia and inaugurated on 15 June 1933), ${ }^{1}$ and transformed into a hotel at the end of the 1960s, with a wellness structure added at the beginning of the 2000s. Inspired by the aestheticism of the famous poet and patriot Gabriele d'Annunzio, the hotel hosted some international celebrities, earning the nickname "VIP hotel." Some sources indicate the probable construction period of the hotel's original nucleus as in the late $1950 \mathrm{~s}^{2}$

In the historical images of 1958, the shelter looks like a rectangular structure, with three levels aboveground (the ground floor about $6 \mathrm{~m} \times 14 \mathrm{~m}$, the first floor about $6 \mathrm{~m} \times 10 \mathrm{~m}$ and the second floor about $4.4 \mathrm{~m} \times 10 \mathrm{~m}$ ), probably in masonry with stone cladding, presenting a $50 \mathrm{~cm}$ thickness. However, this aspect already constituted a transformation over time. In 1968, the Municipality of Farindola sold the shelter to a private company with a clause that required the conversion of the hut into a hotel. In the autumn of the same year, the expansion works started, giving the known "L" shape to the hotel (the sides about $13 \mathrm{~m}$ and $18 \mathrm{~m}$, the width about 10-12 m), with a maximum four levels aboveground, and providing for the inclusion of the historic building. In 2007, the construction of the wellness center started.

The position of the hotel in correspondence to the funnel axis of the avalanche basin (slightly shifted to the orographic left, Fig. 1) played a fundamental role in the dynamics of the impact. The morphology of the area located between the top channel path and the apex of the

\footnotetext{
1 http://www.anaabruzzi.it/?p=441.

2 Carta Archeologica della Provincia di Pescara written by Soprintendenza per i Beni Archeologici per l'Abruzzo, http://news-town.it/ cronaca/14738-hotel-rigopiano,-la-memoria-storica-di-farindolaevento-catastrofico-di-grandi-proporzioni,-imprevedibile,-che-hasuperato-la-dinamica-delle-valanghe-cadute-nel-passato.html.
} 
conoid of the avalanche basin suddenly opens onto an area (the conoid) with a lower slope gradient and larger width. The hotel was thus located at the end of the avalanche flow direction and was hit by the most dense and fastest portion of the avalanche flow.

\section{The General Weather Overview and Snow Scenario}

A snow emergency occurred in Central and South Italy in mid-January 2017. Due to a low-pressure area trapped in the Western Mediterranean, Italy was affected by cold eastern currents that led to hard winter conditions with heavy snowfalls accompanied by strong winds, even at low elevations. An example was the Teramo area where $200 \mathrm{~cm}$ of snow fell in $48 \mathrm{~h}$ at $500 \mathrm{~m}$ asl. ${ }^{3}$ Thus, the avalanche danger degree was stable at level "4-HIGH" for several days in the Central and Abruzzo Apennines. The avalanche danger scale is a five-level scale used to communicate the danger of avalanche. The danger is a function of snowpack stability, its spatial distribution, and the expected size and distribution of avalanches in a specific region.

Because of the unavailability of continuous and reliable observation data referring to the period 15-18 January 2017 for the Rigopiano area (no automatic or manual stations active nearby), the reference data were extrapolated from the synoptic meteorological models (NMM model). ${ }^{4}$ Despite all the uncertainties related to this method, these data proved consistent with records from other automatic or manual stations located in the Central Apennines. For the examined area, only four historical precipitation events between 1985 and 2017 exceeded the threshold of $100 \mathrm{~mm}$ for the Snow Water Equivalent (SWE): in November 2013, February 2015, March 2015, and January 2017, respectively. For a synoptic description of the weather and scenario in the Central Apennines between 15 and 18 January 2017, see Chiambretti and Sofia (2018).

The snowfall started in the afternoon of 15 January and rapidly increased its rates with short breaks during the late morning of the 16th and the early afternoon of the 17 th. The snowfall was accompanied by low air temperatures (air temperature, Ta $<-6{ }^{\circ} \mathrm{C}$, with negative peaks of $-9{ }^{\circ} \mathrm{C}$ ) and was therefore characterized by low density. In the early afternoon of the 16th, a temporary rise of $\mathrm{Ta}$ (from $-9{ }^{\circ} \mathrm{C}$ to about $-7{ }^{\circ} \mathrm{C}$ ) favored the deposition of a graupel (Fierz et al. 2009) layer. During the afternoon of the 17th, a higher density characterized the snowfall, as it occurred with Ta more like those usual for the Apennine's

\footnotetext{
${ }^{3}$ Neve Appennino, http://www.neveappennino.it/.

${ }^{4}$ MeteoBlue $\odot$.
}

winter precipitations. During the night of the 17 th the Ta lowered again rapidly and kept close to $-7 \%-6{ }^{\circ} \mathrm{C}$ until the late morning of the 18th, thus producing a snowfall characterized by a low density. Subsequently, Ta returned to increase slightly, remaining negative during the day, leading to a new increase in snowfall rates in the afternoon. Between 15-19 January, the height of daily new snow at $1880 \mathrm{~m}$ asl exceeded $70-80 \mathrm{~cm}$, while the height of cumulated new snow was close to $356 \mathrm{~cm}$.

The upper cited values for the snow height do not include the wind action on the snow cover distribution. The wind direction was initially from NW-NNW (15th-16th), then from $\mathrm{N}$ and $\mathrm{NNE}$ on the 17th and finally from NNENE on the 18th, which can transport large amounts of fresh snow (Gray and Male 1981). The major phases of erosion, transport, and deposition of fresh snow by, at least, a moderate wind took place in the morning of the 16th, the night between the 16th and 17th, the following morning, a part of the afternoon, the night of the 17th and during the day of the 18th. On 18 January, the thick snowpack was considered "mostly unstable on all steep slopes" as it was made of "layers of dry snow with low cohesion on weakly consolidated layers" already overloaded by a continuous and heavy snowfall that prevented the only road access to the Rigopiano Hotel from the bottom of the valley (Meteomont Service 2017).

\section{Field Investigations and Site Analysis}

A number of multidisciplinary skills were needed to understand the dynamics of this complex phenomenon of a wood-snow avalanche-climatology and meteorology; snow science and engineering; geology and geomorphology; dendrochronology; and structural civil engineering. The complex survey started from field observations, but especially in the release area, the snowpack alteration phenomena made it difficult to ascertain the triggering conditions, the physical properties of the released snowpack, and the area and shape of the starting zone. Nevertheless, the avalanche flow left evident traces on the snow and by entrained debris interacting with trees and shrubs along the avalanche path, allowing the opportunity to record useful data about the direction and approximate depth of both dense and powder snow avalanche parts (Fig. 3).

An accurate survey of the orientation and direction of logs, branches, or other debris flow provided useful evidence about the avalanche dynamic, coupled with minor and topmost branch breakage observations, essential to approximate the height of the powder component or the air blasts associated with the flowing part of the avalanche (Chiambretti et al. 2018). In addition, corrasion and shock 
Fig. 3 The intense

deforestation process caused by the 18 January 2017 avalanche in Farindola, Pescara, Italy significantly enlarged the width of the channel, uprooting and chopping beeches. Beeches uprooted and finely splintered along the track zone. View of the gully upstream of the Rigopiano Hotel. Photograph by Frigo on 12 September 2017

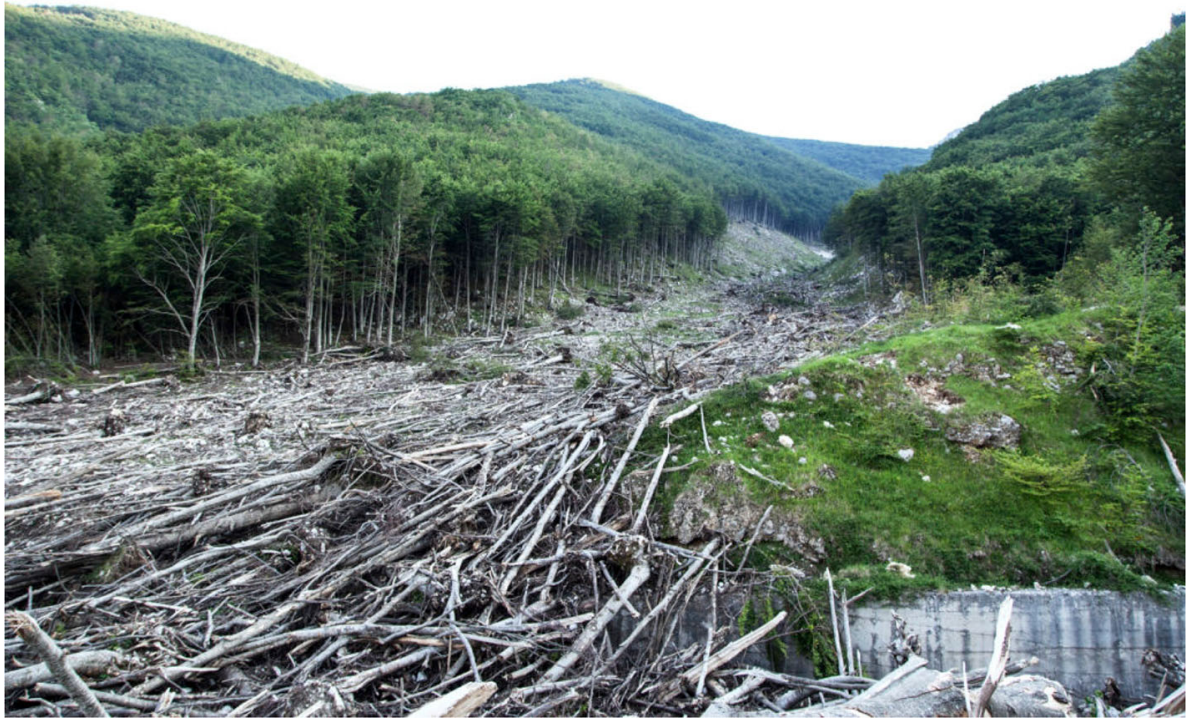

traces on rock outcrops and on soil were surveyed. The magnitude of the 2017 event most likely deleted all traces left by previous avalanches with a similar or slightly smaller extension. The damage suffered by the hotel and the other structures in the avalanche path gave just an estimation of the destructive power of the event and its impact pressure. Based on these field observations, the perimeter of the avalanche basin was plotted with its extreme runout deduced from the trim line, the deposit and debris distribution, as well as the discernible and specific types of vegetation damage left by the flow.

A morphometric and geomorphologic analysis of the basin was carried out, based on the GIS elaboration of the $10 \mathrm{~m}$ resolution and $50 \mathrm{~cm}$ resolution (unmanned aerial vehicle and helicopter photogrammetry) digital terrain model, and a LiDAR and stereoscopic photointerpretation of several aerial photos and high-resolution satellite images of different periods, suitably georeferenced and orthorectified. A comparison between field measurements and georeferenced and orthorectified photos taken by helicopter three days after the event (the first time that the weather was good enough to render the avalanche crown visible) enabled an understanding and assessment of the area of the starting zone.

The evolution of the forest over the years was carefully investigated as well. It is well known that trees play an important role for snowpack characteristics and avalanche dynamics (McClung and Schaerer 1996). However, forests are unable to slow down the flux of large avalanches, especially when they have already reached high speeds (De Quervain 1978; Brang et al. 2006). The evolution of the forest along the Rigopiano slopes was analyzed based on photographic documentation available from the mid-1940s, indicating the natural development of the forest and the modifications of soil use by anthropic activities. Over the years, traditional sheep farming activities decreased significantly, and the management of the forest changed to agricultural uses: firewood. This led to the development of a forest heterogeneous in terms of size and age of the plants. We found young trees less than 25-30 years old and 120-year old trees in the highest part of the forest. These modifications may also have hidden information on old avalanche events.

\section{The Evidence of the Avalanche Dynamics from Site Inspections}

The track of the Rigopiano avalanche of 18 January 2017 is still easy to identify from site inspections, even in the nosnow season, due to the complete destruction of the dense forest. The avalanche basin presents a steep slope $\left(30^{\circ}\right.$ $35^{\circ}$ ), characterized by two regular and planar subbasins with apex sections that are very steeply (up to $40^{\circ}$ ) or extremely steeply $\left(>40^{\circ}\right)$ partly channelized, at about $1900 \mathrm{~m}$ asl. The two subbasins merge, towards the bottom and near the tree line, in a single wide and uniform area characterized by a steep grassy slope, weakly concave and progressively more channeled-probably the runout area for the smallest and more frequent avalanches or debris flows. Here, the track area bifurcated with, on the left, a weakly sinuous channel and, on the right, an important rocky and wooded spur. The on-site inspections revealed that the snow of the avalanche of January 2017 was a dry snow type, confirmed by the flow marks against the gully edges at the extrados of the bends, the snow plastering 
against the obstacles and the broken branches over the deforested limits, the latter significant indicators of a powder component. The spur represents a natural jump for the very rapid flow that deforested it, uprooting adult beeches, incorporating a large amount of wood with little loss of energy.

Usually, this jump was bypassed by slower phenomena, which preferentially used to travel inside the narrow channel on the orographic left. However, a portion of avalanche flow runs along this channel, engraving the first parabolic curve (on the orographic left) in the forest, and then trying to resume the line of maximum slope. However, at the base of the spur, where the two streams met again, the velocity was still too high, and the avalanche carved the second parabolic curve (on the orographic right) inside the forest giving a "bobsleigh" shape to the Rigopiano avalanche basin, well engraved in the forest (Fig. 4). Due to the high speed of the snow flow, the beech forest was not able to reduce its speed. On the contrary, the entrainment of wooden material significantly increased the density of the avalanche mass and, consequentially, the impact of energy against the hotel building.

The ravine exits onto two mixed fans, coalescent, which are characterized by a series of escarpments and slight ridges whose genesis refers to slope gravity processes (debris flows, avalanches, colluvium, and rockfalls). In this basin part, the avalanche continued its devastation, causing the eradication of the trees entrained by its flowing part. This "domino effect" continued downstream (until the impact against the hotel), increasing the inertia and the mass of the avalanche together with its density due to snowpack and beech entrainments.

The entrainment of the forest transformed the snow avalanche into a sort of "debris-flow" made up of snow and wood that struck the hotel with high kinetic energy and considerable impact pressure. The avalanche directly impacted the west side of the multistory structure built in the late 1960s, mainly at the level of the second floor aboveground. Thanks to the slope configuration, the lower building structures on the east side were only marginally impacted and the underground part (the wellness center) remained practically intact. With the terrific thrust due to the vast mass of snow and wood/stone debris, the avalanche impact dislocated the hotel building downhill by almost $50 \mathrm{~m}$ breaking the columns and creeping into the lower and underground floors of the hotel. The avalanche was so fast and fluid that it did not stop after the impact, flowing over the building, dragging the concrete and stone elements with all the inside furnishings for a hundred meters downhill. Many lighter furnishing components, parts of the fence and the plumbing and the lighting system, were transported even farther (up to 300-350 m downhill), together with some of the cars parked in the outside lot and limestone boulders weighing up to about $4000 \mathrm{~kg}$.

At $450 \mathrm{~m}$ away from the hotel, in a flat $\left(<4^{\circ}\right)$ grassy plateau, the snow and debris deposition zone measured almost $4 \mathrm{~m}$ thick. The total runout avalanche distance reached almost $2.3 \mathrm{~km}$ (Fig. 5). The relatively lower deposit upslope and close to the original hotel position, along with the structural damage, indicated that at the impact point the flow still had a very high velocity, that is, it was not yet fully depositing. Most probably, at the altitude of the hotel, the avalanche was no longer accelerating but still maintained a high speed increasing its density due to the entrainment of wood, rocks, and debris (Frigo et al. 2018).

\section{Numerical Avalanche Simulations}

From the data gathered in situ, the avalanche can be considered a fluidized dry snow avalanche, which entrained, along its downhill path, a slightly warmer snow cover (a)

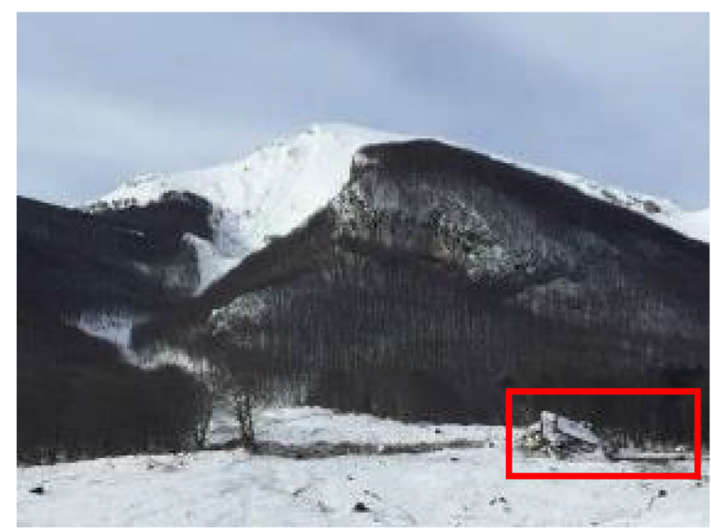

(b)

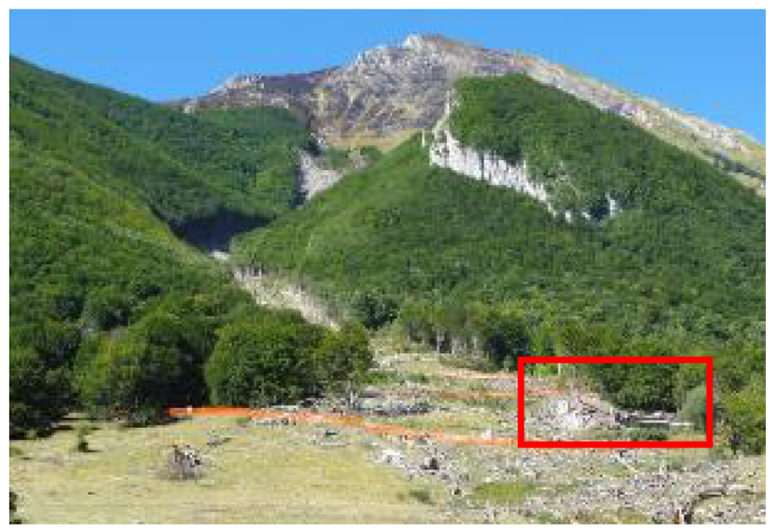

Fig. 4 The avalanche basin in Farindola, Pescara, Italy, immediately after the avalanche event (a) on 28 January 2017; and in the late summer (b) on 12 September 2017 (in the red box, the Rigopiano Hotel). Photograph by Frigo on 28 January 2017 and 12 September 2017 
Fig. 5 High definition satellite image of the Rigopiano site in Farindola, Pescara, Italy. The avalanche track through the forest is clearly visible. At the fan apex, the flowing component expanded laterally occupying almost the entire available section without losing significant speed (in the red box, the debris of Rigopiano Hotel). Source Google Earth Proimage July 2017

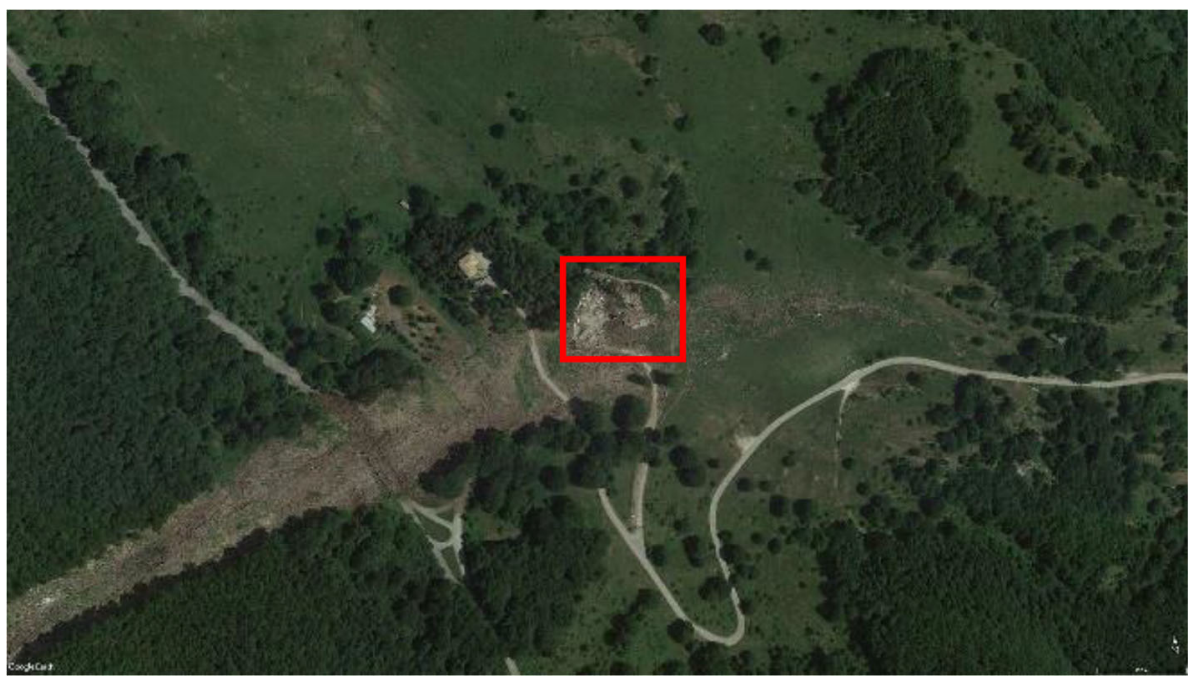

together with trees, rocks, and other debris. The results of the simulations suggested that the snow cover conditions had a significant effect on the avalanche dynamics-for example, the very long runout distance that was measured in the field, while the mix of wood and snow was the most important factor explaining the high momentum at the impact point and the consequent catastrophic collapse of the hotel concrete structure.

The only available testimonies are those of the so-called silent witnesses (for example, trees, boulders, soil, and so on) that allowed the forensic experts to reconstruct broadly the avalanche dynamics of the event as described. There is no eyewitness testimony, and the technical surveys were carried out 10 days after the avalanche, when the rescue operations had ended. It was not even possible to perform prompt photographic surveys for the upslope part because of continuing bad weather and poor visibility conditions.

The forensic experts therefore decided to proceed with the reconstruction of the most probable avalanche dynamics of the event based on a numerical model of the dynamics of snow avalanches, calibrated based on data and factual surveys carried out by the experts, and applying the principles of reverse engineering analysis, applied in forensic investigations. The physical complexity of the Rigopiano avalanche affects the choice of the model able to reproduce best the avalanche behavior. From the field evidence, the Rigopiano event was a snow-wood avalanche with a preponderant (and more destructive) flowing part, with two significant peculiarities:

- the prevalence of the flowing part, highly fluidized due to the medium-high density and dry snow, weak internal friction, and very high velocity;

- the entrainment of many beech trees that transformed the avalanche into a composite snow/wood mixture, dragging tree trunks, rocks, and other debris downstream and providing momentum for the impact on the hotel.

The dynamics of the event, with a starting zone outside the forest and a track zone in a strongly canalized beech forest, turning the snow avalanche into a mixed snow/wood flow, suggested to us to choose the RAMMS (RApid Mass Movement Simulation $)^{5}$ tool for the simulation of the dynamics of rapid movements in $3 \mathrm{D}$ alpine terrain. The RAMMS is a research-based software that can model, although in a parametric way, the effects of the interaction between the avalanche and the wooded area in terms of erosion of the snowpack, loss of energy, and mass variation of the flow, by varying the dynamic parameters (Feistl et al. 2014; Teich et al. 2014). The commercial version of RAMMS (Operational) is dedicated to avalanche experts. However, the model is continually under development. An extended version allows the simulation of fluidized mixed flowing/powder avalanches (Bartelt et al. 2016), and wet snow avalanches (Vera Valero et al. 2015, 2018) with or without forests (Feistl et al. 2015).

A peculiarity of the extended RAMMS avalanche tool (Version March 2017) is the treatment of snow entrainment. The RAMMS entrainment model considers both the thermal and random energy fluxes associated with the avalanche-snow cover interaction (Bartelt et al. 2018). Entrainment of dry, cold snow will contribute to the fluidization of the avalanche core, including the development of disperse flow regimes that include particle splashing (saltation fronts) and the formation of powder clouds. Entrainment of warm snow can damp these processes that lead to heavy, dense flowing avalanches. The avalanche flow regime depends on the temperature of the released and entrained snow. Significant meltwater can be generated that

\footnotetext{
5 http://ramms.slf.ch/ramms/.
} 
leads to lubricated shear surfaces and a reduction of the flow friction (long runout). The extended version of RAMMS (Version March 2017), like the operational version, applies Voellmy rheology to model flow friction (Christen et al. 2010). In the extended version, the friction parameters (Coulomb and Turbulent friction) change dynamically with the degree of fluidization (bulk flow density). This change is controlled by snow temperature as well as by the entrainment mechanism (Bartelt et al. 2018).

Another feature of the extended RAMMS software is the ability to include mountain forests in the simulations (Feistl et al. 2014, 2015). Forests are included by first defining forested areas within the simulation domain. The forests can vary with respect to the tree species, age (stem diameter and tree height), as well as stand density. These parameters define the breaking stress needed to fracture or uproot trees. If the trees are broken, they offer little resistance, other than the energy required to accelerate the woody debris to the speed of the avalanche. If the trees do not break, they offer more effective protection. The avalanche mass piles up behind tree stems, removing snow from the avalanche. With the removal of mass, detrainment causes the avalanche to decrease in speed, limiting both the runout and lateral spread of the avalanche. The loss of the momentum and of the mass (detrainment) due to the resistance of trees to avalanche flow is therefore considered, although in a parametric way.

\subsection{Inputs to the Avalanche Model}

Due to the snowpack and weather conditions, it was not safe to conduct a field survey and to collect data immediately after the avalanche event. The hazard level remained high for the following days. Only on 20 and 21 January two snow profiles could finally be carried out. Later, both during the winter and the subsequent spring/summer seasons, several field surveys were carried out in order to collect data along the track to assess the avalanche path, forest damage, and structural damage extent. Therefore, some uncertainties are still present in the model inputs (for example, the exact fracture depth and the exact snow cover conditions). In the following, the main inputs of the simulation are outlined.

\subsubsection{Release Zone}

The release area was observed for the first time during a helicopter flyover three snowy days after the event. The release area used for the simulation was determined on the basis of the few traces of slab fractures observed on the slope, integrated with assumptions taken from specific literature about potential avalanche release areas (McClung and Schaerer 1996; Maggioni and Gruber 2003; Schweizer et al. 2003). The release area developed from 1890 to $1760 \mathrm{~m}$ asl with a mean slope angle of $32^{\circ}$ (Fig. 6).

The fracture depth was determined from the combined analyses of the data gathered from the snow profile digs at the hotel (1120 m asl) and, in the surroundings, at different altitudes and exposures, for example, at snow stations of the Meteomont Service (Chiambretti et al. 2018; Chiambretti and Sofia 2018).

The determination of the fracture depth began from the thickness of the new fallen snow at the altitude of the hotel, which was estimated to be equal to $1.9 \mathrm{~m}$. This value was derived from about $1.4 \mathrm{~m}$ of new snow measured in the snow profiles made 2-3 days after the event, together with the observed signs of settlement around tree trunks (about $50 \mathrm{~cm}$ of settlement after the event). From this value, we applied an altitude gradient equal to $5 \mathrm{~cm} / 100 \mathrm{~m}$ altitude rise, as used in other parts of Italy (Barbolini et al. 2005) and in Switzerland (SLF 1999). Other corrections (SLF 1999; Barbolini 2007) were used to take into consideration the mean altitude $\left(1850 \mathrm{~m}\right.$ asl) and slope angle $\left(32^{\circ}\right)$ of the release area plus the additional load due to snow drift $(50 \mathrm{~cm})$. Several visible signs of snowdrift were observed in the area-the intense wind was blowing from NNE during the snowfall and immediately after. Finally, from the value of $1.9 \mathrm{~m}$ at about $1100 \mathrm{~m}$ asl up to the release zone, we determined an input value for the fracture depth equal to $2 \mathrm{~m}$ (Table 1 ). This led to a total release volume of about $77.000 \mathrm{~m}^{3}$.

The average snow density of the slab was estimated to be equal to $250 \mathrm{~kg} / \mathrm{m}^{3}$ (Table 1). This value was determined combining the measurements of the new snow gathered from the snow profiles together with very possible densification due to snowdrift. The total release mass was therefore 19,255 tons.

\subsubsection{Snow Cover Characteristics and Erosion Parameters}

The snow cover along the track presented characteristics that were determined based on the collected snow profiles. The erodible snow cover, used as input in the model, is considered to be made of two layers (named " 1 " and " 2 " in Table 1): a superficial layer of $1.5 \mathrm{~m}$ thickness with a density of $200 \mathrm{~kg} / \mathrm{m}^{3}$ and a temperature of $-3{ }^{\circ} \mathrm{C}$; a bottom layer of $0.8 \mathrm{~m}$ thickness with a density of $250 \mathrm{~kg} /$ $\mathrm{m}^{3}$ and a temperature of $-2{ }^{\circ} \mathrm{C}$. According to the assumption that the superficial layer is considered more erodible than the bottom one, we chose the two model parameters ( $\mathrm{K}$ and epsilon) related to erosion processes (Table 1). The erodible snow height within the forested areas is variable according to the characteristics of the trees, and to the canopy cover and forest density, which determine the capacity of snowfall interception by the trees. 
Fig. 6 Release area (in blue) of the 2017 Rigopiano avalanche in Farindola, Pescara, Italy, over a slope angle map (a) and over the orthophoto (b). Source $10 \mathrm{~m}$ resolution Digital Terrain Model of Abruzzo region. http:// opendata.regione.abruzzo.it/ opendata/Modello_digitale_del_ terreno_risoluzione_10x10_ metri (a)

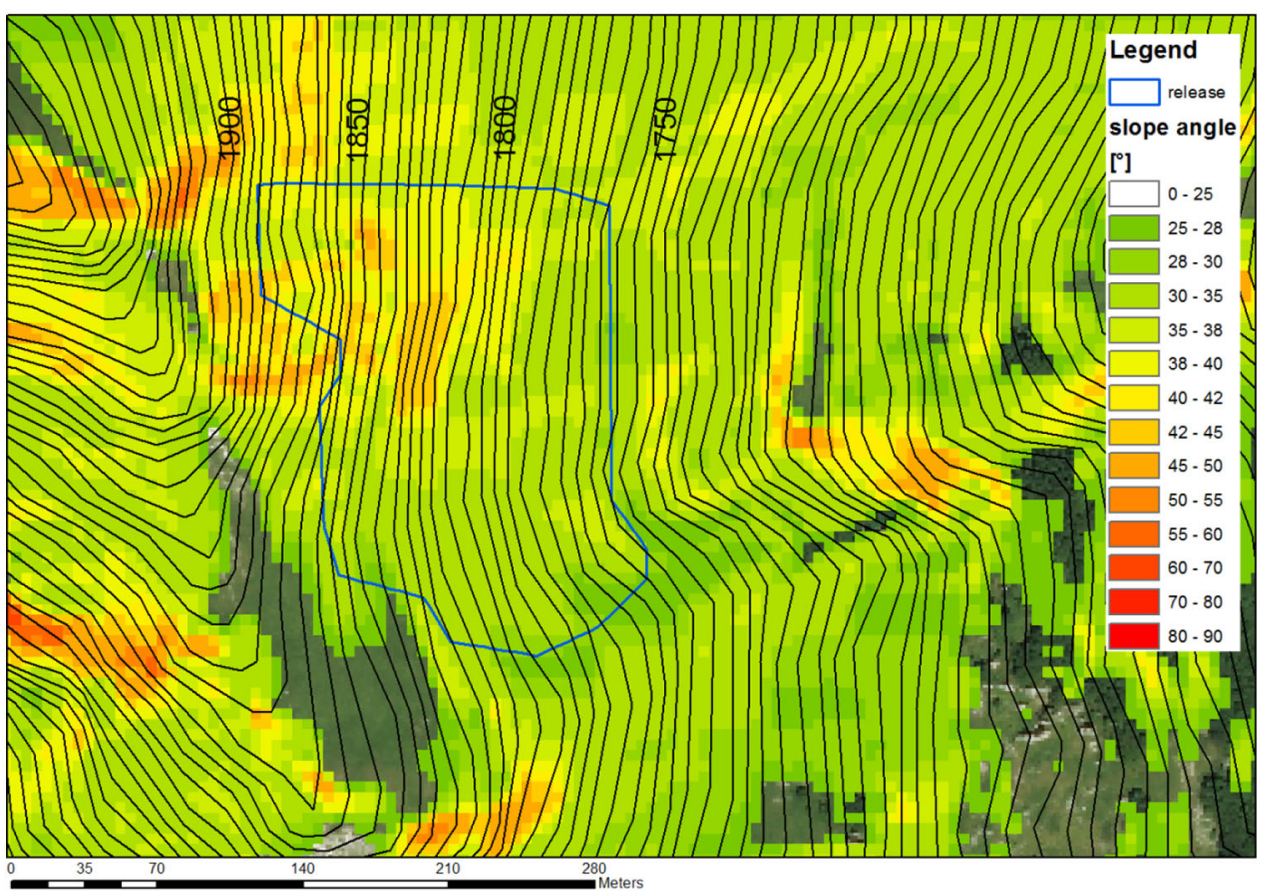

(b)

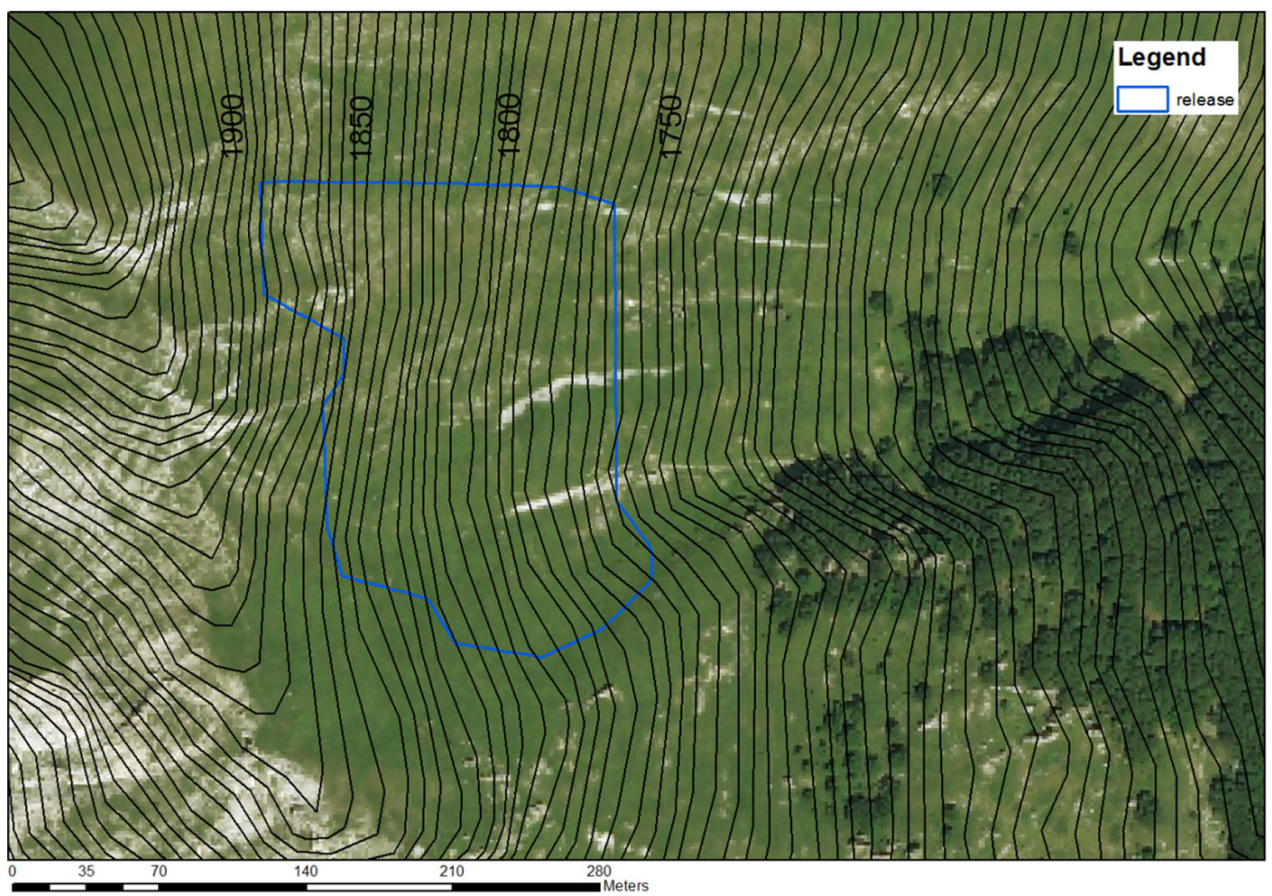

Two forested areas were identified: a large area from about $1600-1160 \mathrm{~m}$ asl of younger beeches of $25 \mathrm{~cm}$ diameter with high canopy coverage, and a smaller area closer to the hotel (below the crossroads between the two provincial

beeches (Fagus sylvatica), whose characteristics were determined through aerial photo analyses and fieldwork. 
Table 1 Input parameters to the Rapid Mass Movement Simulation-RAMM avalanche tool (extended version, March 2017)

\begin{tabular}{|c|c|c|c|}
\hline Parameter & Value & Parameter & Value \\
\hline Fracture depth (m) & 2 & Layer 1 & \\
\hline Release volume $\left(\mathrm{m}^{3}\right)$ & 77,000 & Erodible snow height (m) & 1.5 \\
\hline Release density $\left(\mathrm{kg} / \mathrm{m}^{3}\right)$ & 250 & Erodible snow density $\left(\mathrm{kg} / \mathrm{m}^{3}\right)$ & 200 \\
\hline Release $\mathrm{T}\left({ }^{\circ} \mathrm{C}\right)$ & -3 & Erodible snow $\mathrm{T}\left({ }^{\circ} \mathrm{C}\right)$ & -3 \\
\hline Avalanche density $\left(\mathrm{kg} / \mathrm{m}^{3}\right)$ & 450 & $\mathrm{~K}$ & 2 \\
\hline $\mathrm{mu}_{0}$ & 0.55 & Epsilon & 0.1 \\
\hline $\mathrm{xi}_{0}\left(\mathrm{~m} / \mathrm{s}^{2}\right)$ & 2000 & & \\
\hline Cohesion $(\mathrm{Pa})$ & 100 & Layer 2 & \\
\hline Generate & 0.07 & Erodible snow height $(\mathrm{m})$ & 0.8 \\
\hline $\mathrm{R}_{0}\left(\mathrm{~kJ} / \mathrm{m}^{3}\right)$ & 2 & Erodible snow density $\left(\mathrm{kg} / \mathrm{m}^{3}\right)$ & 250 \\
\hline mu-wet & 0.12 & Erodible snow T $\left({ }^{\circ} \mathrm{C}\right)$ & -2 \\
\hline Dry-wet transition $(\mathrm{mm})$ & 0.1 & K & 0.5 \\
\hline K-forest up & 15 & Epsilon & 0 \\
\hline $\mathrm{K}$-forest low & 28 & & \\
\hline
\end{tabular}

roads no. 8 and no. 37 at $1160 \mathrm{~m}$ asl) of beeches of $70 \mathrm{~cm}$ diameter with medium canopy coverage.

\subsubsection{Other Model Input Parameters}

Table 1 also shows the inputs related to cohesion, random kinetic energy $\left(\mathrm{R}_{0}, \mathrm{mu}_{0}\right.$, and $\left.\mathrm{xi}_{0}\right)$, avalanche density, and transition between dry and wet flow, for completeness of information for the RAMMS code experts. In particular, the choice of $450 \mathrm{~kg} / \mathrm{m}^{3}$ for the avalanche density was made according to the consideration that the avalanche was finally a mix of snow and trees (wood density of beeches is about $700 \mathrm{~kg} / \mathrm{m}^{3}$ ). Therefore, in the investigation of the impact pressures, such density value well represents this mix.

\subsection{Outputs of the Avalanche Model}

The mapped perimeter of the surveyed deposition area (Fig. 7, in blue the outline of the fluidized part of the avalanche, and in violet the powder part of the avalanche) provided the most reliable guide to back-calculating the Rigopiano avalanche event. The spatial extent of the deposition areas could only be simulated by correctly choosing the temperature of the snow cover along the path. Only by selecting subzero temperatures of snow cover in the release zone $\left(\mathrm{T}=-3{ }^{\circ} \mathrm{C}\right)$, as well as warmer temperatures in the entrainment zone ( $\mathrm{T}$ between -3 and $-1{ }^{\circ} \mathrm{C}$ ), dissipative heat led to meltwater production, providing the lubrication necessary to model the extreme runout of the avalanche. The simulated avalanche stopped at an elevation of $1080 \mathrm{~m}$ asl at the provincial road no. 8
(Fig. 7). The modeled snow temperature in the deposit is about $-1.1{ }^{\circ} \mathrm{C}$. The water content reaches values of up to $6 \mathrm{~mm} / \mathrm{m}^{2}$ (Fig. 8), which means that, over a deposition of $2.1 \mathrm{~m}$, the snow reached a volumetric liquid water content of about $3 \%$.

Because of the colder temperatures in the upper track region, the simulated avalanche reaches a high peak velocity along the track $(44 \mathrm{~m} / \mathrm{s})$, at about $1450 \mathrm{~m}$ asl, before the first sharp turn to the right (Fig. 9a and Table 2).

Another reliable guide to evaluating the reliability of the conducted simulation is the track of the forest devastation. The model simulated the area where the forest is destroyed in relation to the avalanche's destructive power. Usually the interaction between the avalanche flow and the forest results in a loss of mass, which is detrained from the avalanche flow by the tree trunks. Instead, in this case, the area where the trees are destroyed represents where the avalanche overcomes the resistance of the beech trees (Fig. 10).

The simulated avalanche reaches the hotel building $69 \mathrm{~s}$ after release, traveling with a speed of $30.6 \mathrm{~m} / \mathrm{s}$, with a slightly warmer temperature $\left(\mathrm{T}=-1.1^{\circ} \mathrm{C}\right)$ than the avalanche in sliding phase and high flow densities (more than $400 \mathrm{~kg} / \mathrm{m}^{3}$, given by numerical model). The simulated impact pressures reach very high values along the track (see Fig. 9b). In the area close to the hotel, the avalanche attains pressure values above $300 \mathrm{kPa}$. At the impact, the peak of the impact pressure, calculated as $r h o \times v^{2}$ (where rho is density and $v$ velocity) is estimated equal to $393 \mathrm{kPa}$. The avalanche entrained almost $103,000 \mathrm{~m}^{3}$ of snow. 


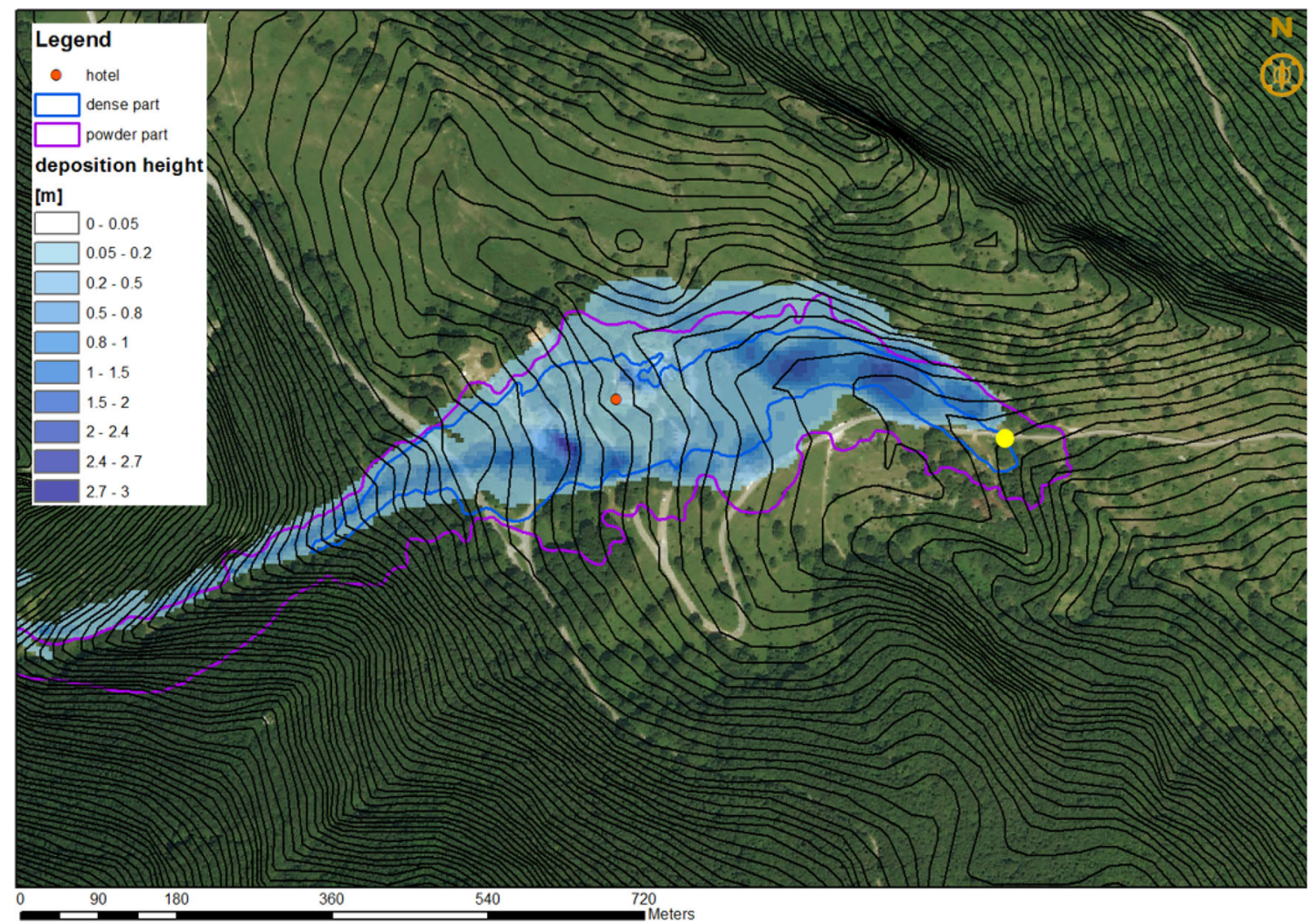

Fig. 7 Simulated deposition height of the 2017 Rigopiano avalanche in Farindola, Pescara, Italy-blue area. The blue and violet lines represent the outline of the dense and powder parts of the avalanche, as determined from the field surveys. The red dot indicates the location of the hotel, the yellow dot, the location of the provincial road no. 8. Source $10 \mathrm{~m}$ resolution Digital Terrain Model of Abruzzo region. http://opendata.regione.abruzzo.it/opendata/Modello_digi tale_del_terreno_risoluzione_10x10_metri
Fig. 8 Simulated water content in the deposition zone of the 2017 Rigopiano avalanche in Farindola, Pescara, Italy. The red dot indicates the location of the hotel

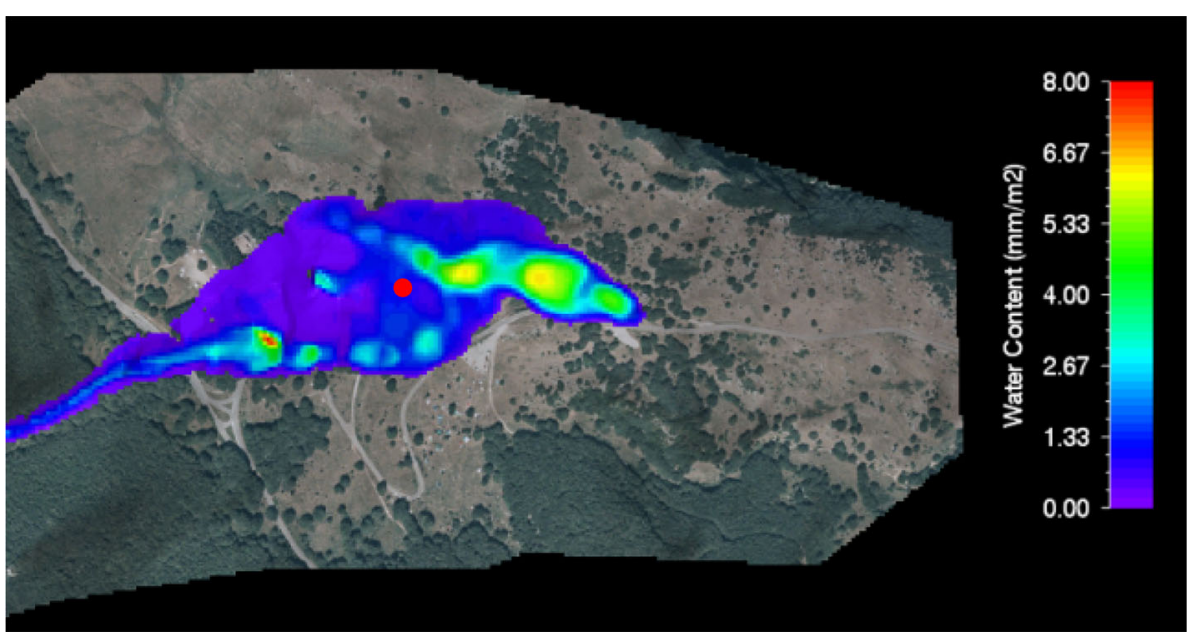

\section{Discussion}

This article reports on the most plausible reconstruction of the dynamics of the tragic avalanche that occurred on 18 January 2017 in Rigopiano, Farindola, Pescara (Gran Sasso Massif, Italy). Three of the authors were directly involved in the immediate survey and investigation process and performed the appropriate forensic analyses.

Three main directions were followed in order to achieve a coherent and sound modeling of the event. The first concerned the analysis and reconstruction of the snowfall and meteorological data of 15-18 January 2017, which were characterized by the relevant daily and cumulated 
(a)

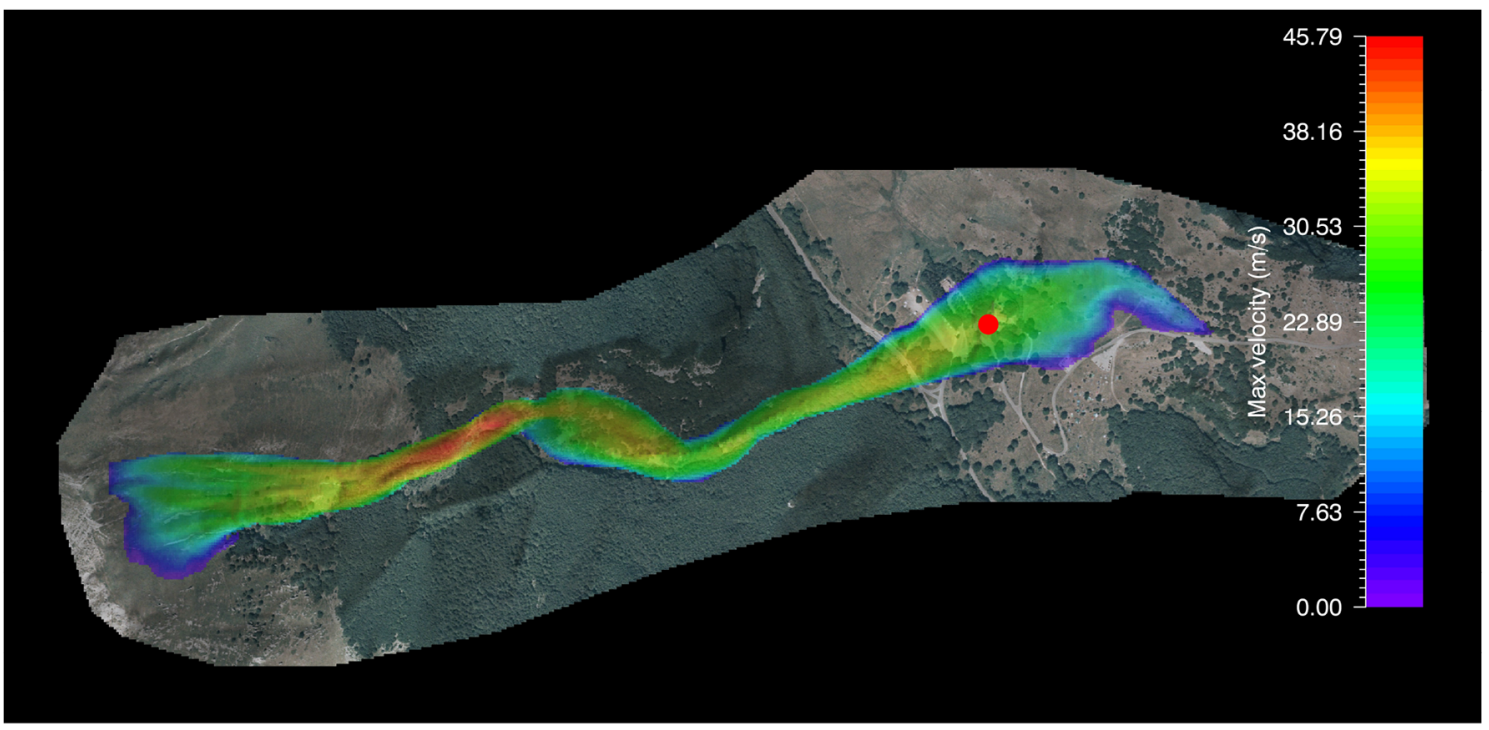

(b)

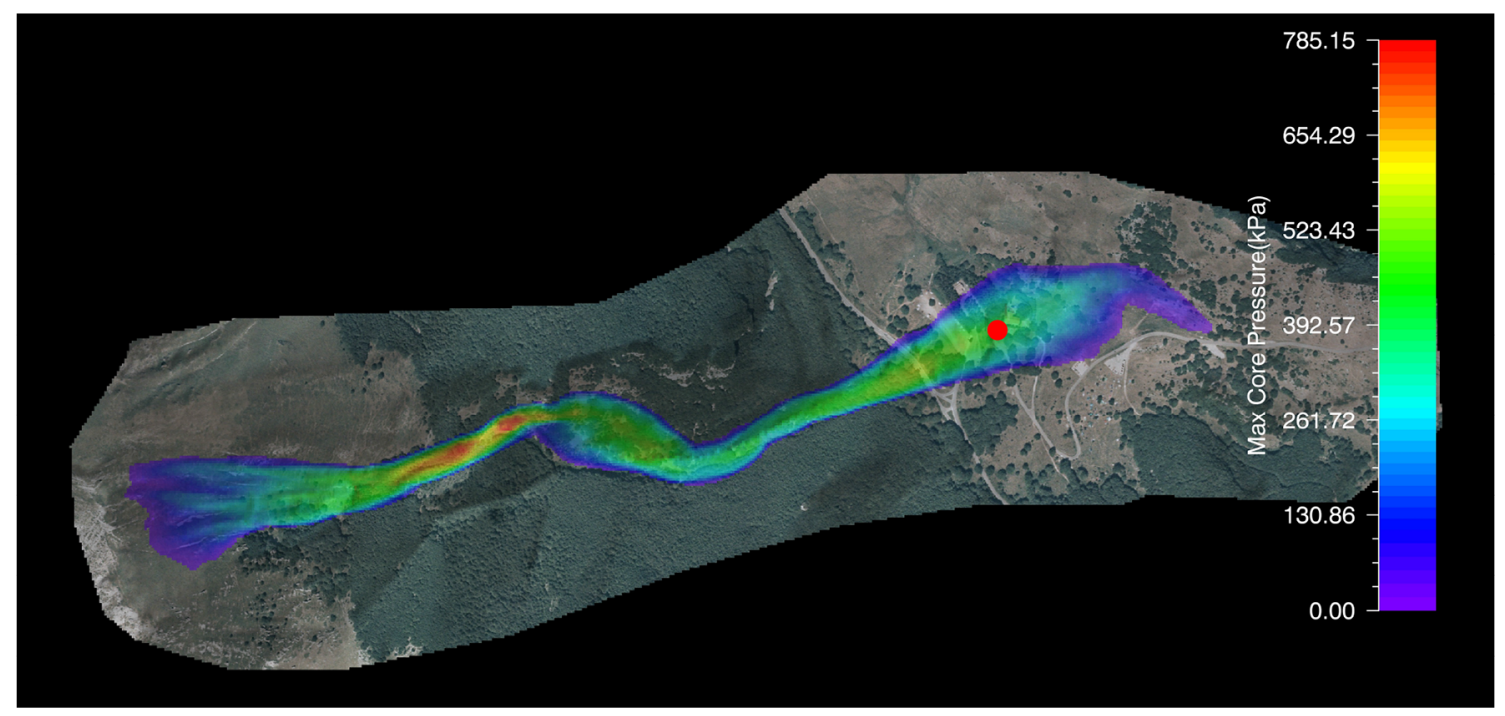

Fig. 9 Simulated variables for the 2017 Rigopiano avalanche in Farindola, Pescara, Italy: a the maximum velocity of the core along the avalanche track; $\mathbf{b}$ the impact pressure of the fluidized part (core)

Table 2 Model outputs for the 2017 avalanche at the position of the Rigopiano Hotel in Farindola, Pescara, Italy

\begin{tabular}{ll}
\hline Dynamical variable & Value \\
\hline Fluidized part (core) & \\
Height $(\mathrm{m})$ & 0.1 \\
Max height $(\mathrm{m})$ & 2 \\
Max velocity $(\mathrm{m} / \mathrm{s})$ & 30.6 \\
Max density $\left(\mathrm{kg} / \mathrm{m}^{3}\right)$ & 450 \\
Powder part & \\
Max velocity $(\mathrm{m} / \mathrm{s})$ & 25 \\
Max density $\left(\mathrm{kg} / \mathrm{m}^{3}\right)$ & 2.6 \\
\hline
\end{tabular}

of the avalanche that destroyed the hotel (the red dot indicates the location of the hotel)

heights of snow on the ground. The second concerned the in-depth site inspections, including a survey of the avalanche perimeter and the forest damage, as well as the geological, morphological, and topographical analysis of the avalanche basin. These two directions of analysis are only briefly summarized; more space was devoted to the third research direction - the numerical modeling aimed at understanding the peculiar dynamics of the avalanche event.

Due to the absence of eyewitnesses and the impossibility of performing a quick post-event survey, the dynamics of the event were analyzed by an inverse analysis coupled 
Fig. 10 Area of tree destruction caused by the 2017 avalanche in Farindola, Pescara, Italy: the modeled area (left) compared with the real deforested track in the forest (right). Source Google Earth
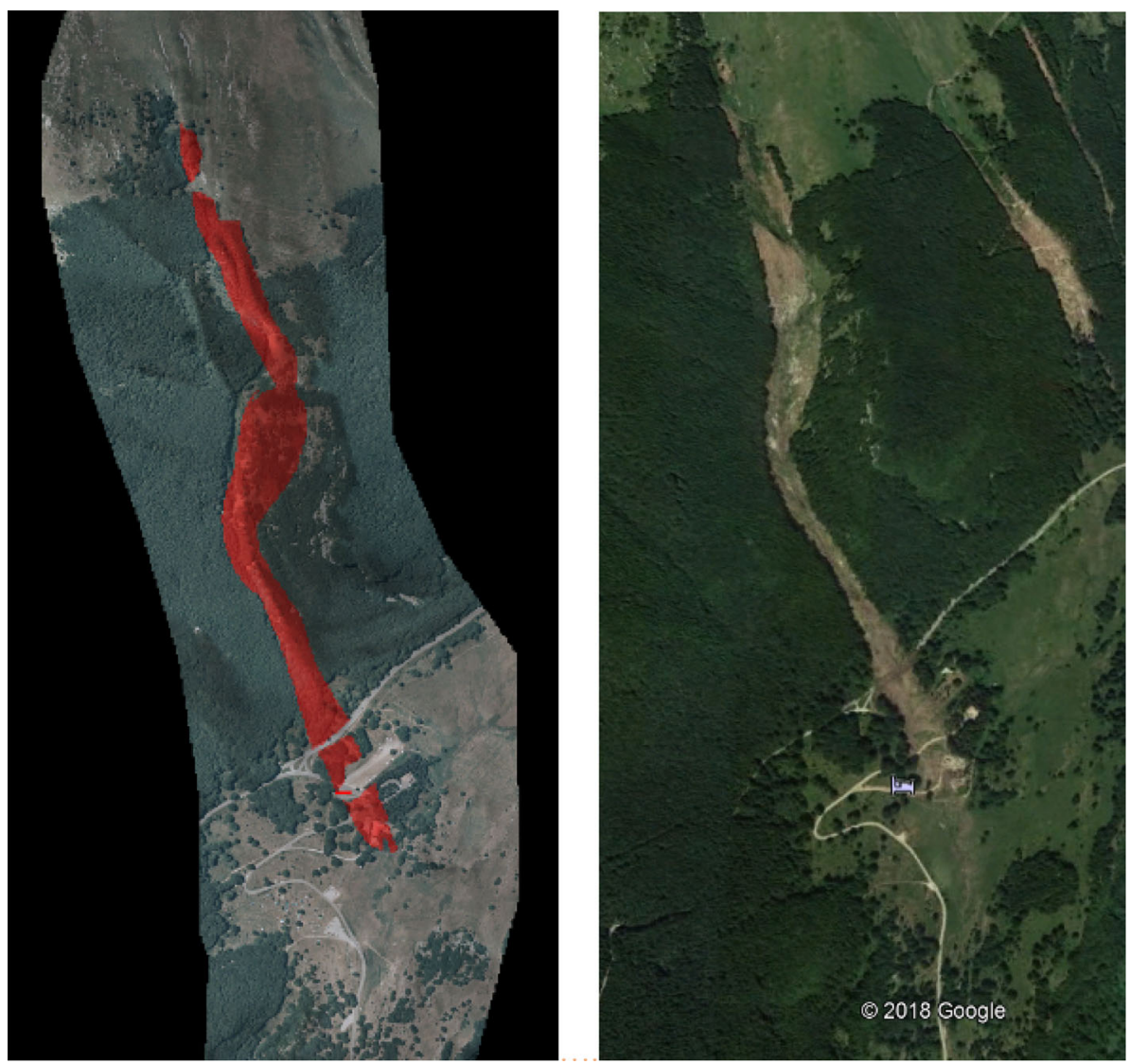

with the use of a specific numerical model. The objective of the dynamic analysis was to estimate the pressure, velocity, density, and direction at the point of impact between the avalanche and the hotel in the context of a reverse engineering analysis, necessary for explaining the terrible destruction of the reinforced concrete structure.

This article reports the technical and scientific motivations that provided the inputs of the numerical model. The model was also calibrated by comparing the various parameters with site inspections and surveys, with the measured perimeter of the fluid and powder parts of the avalanche, with the destroyed forest areas, and with the extension of the runout deposition zone.

The numerical RAMMS (Version March 2017) model was able to reproduce the field information and the two main peculiarities of the avalanche event: the high destructive potential while running through the forest (explaining the high momentum at impact) and the high fluidization of the core part that explains the speed. This was possible based on the specific tools of the model that permit modeling of the avalanche interaction with the forest. Moreover, RAMMS offers the possibility to vary: (1) the snowpack temperature along the track for snow entrainment; and (2) the core density of the avalanche.
Regarding the structural analysis of the building collapse, the key output provided by the numerical simulation is the impact pressure which, although extremely high, is totally consistent when compared to the displacement of the entire structure (by almost $50 \mathrm{~m}$ ) and to the overall damage suffered by the structure.

With respect to avalanche risk, taking into account magnitude and potential damage caused by events, a final evaluation can be performed based on the "Intensity scale for avalanche risk" presented by Rapin (2002). Divided into five degrees (from 1-very low, to 5-very high), the scale is defined based on physical parameters (the surface affected by the event, the average thickness detachment, the deposited volume, the impact pressure, and so on) that define a grade of magnitude of the event and the foreseeable effects on people, buildings, infrastructures, defense structures, and so on, that are potentially imposed by the avalanche phenomenon. Based on this scale of risk, the event of 18 January 2017 in Rigopiano would be placed between the grades 4-High and 5-Very high (Table 3; Chiaia et al. 2017). 
Table 3 Classification of the 18 January 2017 Rigopiano avalanche in Farindola, Pescara, Italy, based on the "Intensity scale for avalanche risk"

\begin{tabular}{lll}
\hline Grade & Physical parameters (order of magnitude) & Other criteria \\
\hline 4 & Affected surface: $\sim 20$ ha & Eccentric/rare trajectory: possible \\
High & Average slab thickness: $\sim 150 \mathrm{~cm}$ & Avalanche inside many others: frequent \\
& Deposited volume: $\sim 80,000 \mathrm{~m}^{3}$ & Temporary control measures (evacuation \\
& Impact pressure: $\sim 200 \mathrm{kPa}$ & or restrictions): possible \\
5 & Affected surface: $\sim 50 \mathrm{ha}$ & Eccentric/rare trajectory: extended/frequent \\
Very high & Average slab thickness: $\sim 250 \mathrm{~cm}$ & Temporary control measures (evacuation \\
& Deposited volume: $\geq 400,000 \mathrm{~m}^{3}$ & or restrictions): generalized
\end{tabular}

\begin{tabular}{lll}
\hline Grade & Foreseeable effects on the stakes (part 1) & \\
\cline { 2 - 3 } & People & Buildings \\
\hline 4 & Nearby observer panicking & Significant structural damage: \\
High & Person carried along: & Walls: leveling (possible by level of construction), multiple collapses; \\
& Almost systematic serious injury; & Roof: destruction \\
& Rapid and very frequent death & \\
& & Buildings touched: almost total destruction \\
& & Often total burying \\
5 & Observer panicking & Total structural damage, generalized ruin: \\
Very high & Person carried along: & Walls: leveling, systematic collapses; \\
& Almost systematic fatal injury; & Particularly reinforced concrete structures: \\
& Instantaneous death & fissuring/at least partial destruction \\
\hline
\end{tabular}

\begin{tabular}{|c|c|c|}
\hline \multirow[t]{2}{*}{ Grade } & \multicolumn{2}{|l|}{ Foreseeable effects on the stakes (part 2) } \\
\hline & Infrastructures and works & Natural and agricultural spaces \\
\hline 4 & Significant damage: & Destruction of about 10 ha of forest \\
\hline \multirow[t]{7}{*}{ High } & $\begin{array}{l}\text { Superstructure not especially adapted } \\
\text { and forming obstacle: generalized }\end{array}$ & Pulling out and transport of rocks bigger than $1 \mathrm{~m}^{3}$ \\
\hline & destruction; & Generation of a wave in a lake \\
\hline & Locomotive: possible turnaround & $\begin{array}{l}\text { Notorious temporary modification of local topography (deposit of } \\
\text { snow); }\end{array}$ \\
\hline & $\begin{array}{l}\text { Total cover and/or damage over a significant length of } \\
\text { roadway }\end{array}$ & Possible formation of a dam and a lake \\
\hline & Engineering avalanche works: & \\
\hline & Possible partial overflow; & \\
\hline & Possible partial destruction & \\
\hline 5 & Very significant and generalized damage & Very wide destruction of any shrubby vegetation \\
\hline \multirow{3}{*}{$\begin{array}{l}\text { Very } \\
\text { high }\end{array}$} & Engineering avalanche works: & Landscape radically transformed by this destruction \\
\hline & Possible repeated and/or extended overflow, & Strong accumulation of transported things \\
\hline & Possible frequent and/or extended destruction & \\
\hline \multicolumn{3}{|c|}{ Source Rapin (2002) } \\
\hline
\end{tabular}

\section{Conclusion}

Unlike in the Alps, where mountain villages and winter sport resorts developed, in central Italy avalanche phenomena often interact with very little inhabited areas. This creates a partial loss of memory with respect to past major avalanche events and leads to less awareness of the danger of these sites. Therefore, the risk associated with the location where the Rigopiano Hotel was built was underestimated with respect to the morphology of the avalanche basin and the site accessibility (that is, road passability under avalanche danger). 
The absence of geomorphological, meteorological, and avalanche dynamic studies convinced the planners and designers that the hotel was not potentially subjected to avalanche interference, and thus it was built without considering any structural avalanche-proof regulations. This misconception is underlined by the Tito Acerbo mountain refuge, which remained almost intact and unaffected by the avalanche of 18 January 2017 due to its position outside of the main avalanche channel flow. The dynamical avalanche studies would have indicated the necessity of measures of mitigation of avalanche risk-for example, active and passive defense structures, widely used at anthropized avalanche sites in the Alps, like snow dams, snow umbrellas, and deflectors. Alternatively, another measure could have been the preventive controlled artificial release of the avalanche from the top basin with the help of explosives or gas detonations.

Another indirect mitigation measure for the snow and avalanche risk could have been the development of a rescue plan to manage safely the passability of the provincial roads leading to Rigopiano. According to the snow and weather conditions foreseen by the avalanche bulletin, this management action would have led not only to the closure of the provincial road, but also to the temporary closure of the Rigopiano Hotel with timely evacuation of guests and staff. To date, the hotel has not been rebuilt.

Acknowledgments The authors would like to thank Francois Rapin (Institut national de recherche en sciences et technologies pour l'environnement et l'agriculture-IRSTEA) and Stephane Roudnitska (Office National des Forêts-ONF) for useful discussion and constructive debate.

Open Access This article is licensed under a Creative Commons Attribution 4.0 International License, which permits use, sharing, adaptation, distribution and reproduction in any medium or format, as long as you give appropriate credit to the original author(s) and the source, provide a link to the Creative Commons licence, and indicate if changes were made. The images or other third party material in this article are included in the article's Creative Commons licence, unless indicated otherwise in a credit line to the material. If material is not included in the article's Creative Commons licence and your intended use is not permitted by statutory regulation or exceeds the permitted use, you will need to obtain permission directly from the copyright holder. To view a copy of this licence, visit http://creativecommons. org/licenses/by/4.0/.

\section{References}

Barbolini, M., L. Natale, G. Tecilla, and M. Cordola. 2005. Methodological guidelines for the perimetration of areas exposed to avalanche danger (Linee guida metodologiche per la perimetrazione delle aree esposte al pericolo di valanghe). AINEVA e Dipartimento di Ingegneria idraulica ed ambientale dell'Università degli Studi di Pavia. Technical report. https://docplayer.it/ 7174673-Linee-guida-metodologiche-per-la-perimetrazione- delle-aree-esposte-al-pericolo-di-valanghe.html. Accessed 23 Sept 2020 (in Italian).

Barbolini, M. 2007. Definition of the project values for standard snow parameters to prevent avalanche risk in Aosta Valley (Definizione dei valori di progetto di parametri nivometrici standard per la prevenzione del rischio valanghivo sul territorio valdostano). Regione Autonoma Valle d'Aosta (updated August 2013). Technical report. https://www.regione.vda.it/territorio/ territorio/parametrinivometrici/pages/Informazioni.htm. Accessed 23 Sept 2020 (in Italian).

Bartelt, P., O. Buser, C. Vera Valero, and Y. Bühler. 2016. Configurational energy and the formation of mixed flowing powder snow ice avalanches. Annals of Glaciology 57(71): 179-187.

Bartelt, P., M. Christen, Y. Bühler, A. Caviezel, and O. Buser. 2018. Snow entrainment: Avalanche interaction with an erodible substrate. In Proceedings of the International Snow Science Workshop 2018, 7-12 October 2018, Innsbruck, Austria, 716-720.

Berthet-Rambaud, P., A. Limam, P. Roenelle, F. Rapin, J-M. Tacnet, and J. Mazars. 2007. Avalanche action on rigid structures: backanalysis of Taconnaz deflective walls' collapse in February 1999. Cold Regions Science and Technology 47(1-2): 16-31.

Brang, P., W. Schönenberger, M. Frehner, R. Schwitter, J.J. Thormann, and B. Wasser. 2006. Management of protection forests in the European Alps-An overview. Forest Snow and Landscape Research 80(1): 23-44.

Brugnara, Y., S. Brönnimann, M. Zamuriano, J. Schild, C. Rohr, and D.M. Segesser. 2017. Reanalysis sheds light on 1916 avalanche disaster. ECMWF Newsletter, No. 151, April 2017. https://www. ecmwf.int/en/newsletter/151/meteorology/reanalysis-shedslight-1916-avalanche-disaster. Accessed 20 Sept 2020.

Chiaia, B., B. Frigo, I. Chiambretti, S. Marello, and M. Maggioni. 2017. The Rigopiano avalanche: Dynamic analysis (La valanga di Rigopiano: l'analisi dinamica). In Forensic Engineering, Collapses, Structural Reliability and Consolidation (Ingegneria Forense, Crolli, Affidabilità strutturale e Consolidamento), ed. N. Augenti, and F. Bontempi, 457-468. Palermo: Tipografia Priulla (in Italian).

Chiambretti, I., and S. Sofia. 2018. Winter 2016-2017 snowfall and avalanche emergency management in Italy (Central Apennines) - a review. In Proceedings of the International Snow Science Workshop 2018, 7-12 October 2018, Innsbruck, Austria, $1445-1449$.

Chiambretti, I., B. Chiaia, B. Frigo, S. Marello, M. Maggioni, R. Fantucci, and M. Bernabei. 2018. The $18^{\text {th }}$ January 2017 Rigopiano avalanche disaster in Italy-Analysis of the applied forensic field investigation techniques. In Proceedings of the International Snow Science Workshop 2018, 7-12 October 2018, Innsbruck, Austria, 1208-1212.

Christen, M., J. Kowalski, and P. Bartelt. 2010. RAMMS: Numerical simulation of dense snow avalanches in three-dimensional terrain. Cold Regions Science and Technology 63(1-2): 1-14.

De Quervain, M. 1978. Forest and avalanches (Wald und Lawinen). In Proceedings of the IUFRO Seminar Mountain Forests and Avalanches, 25-28 September 1978, Davos, Switzerland, 219-231 (in German).

Feistl, T., P. Bebi, M. Teich, Y. Bühler, M. Christen, K. Thuro, and P. Bartelt. 2014. Observations and modeling of the braking effect of forests on small and medium avalanches. Journal of Glaciology 60(219): 124-138.

Feistl, T., P. Bebi, M. Christen, S. Margreth, L. Diefenbach, and P. Bartelt. 2015. Forest damage and avalanche flow regime. Natural Hazards and Earth System Sciences 15(6): 1275-1288.

Fierz, C., R.L. Armstrong, Y. Durand, P. Etchevers, E. Greene, D.M. McClung, K. Nishimura, P.K. Satyawali, and S.A. Sokratov. 
2009. The international classification for seasonal snow on the ground. IHP-VII technical documents in hydrology $\mathrm{N}^{\circ} 83$, IACS contribution $\mathrm{N}^{\circ} 1$. Paris: UNESCO-IHP.

Frigo, B., B. Chiaia, I. Chiambretti, P. Bartelt, M. Maggioni, and M. Freppaz. 2018. The January $18^{\text {th }} 2017$ Rigopiano avalanche disaster in Italy-Analysis of the avalanche dynamics. In Proceedings of the International Snow Science Workshop 2018, 7-12 October 2018, Innsbruck, Austria, 6-10.

Gray, D.M., and D.H. Male. 1981. Handbook of snow: Principle, process, management and use. Caldwell, NJ: The Blackburn Press.

Höller, P. 2009. Avalanche cycles in Austria: an analysis of the major events in the last 50 years. Natural Hazards 48(3): 399-424.

Maggioni, M., and U. Gruber. 2003. The influence of topographic parameters on avalanche release dimension and frequency. Cold Regions Science and Technology 37(3): 407-419.

McClung, D., and P. Schaerer. 1996. The avalanche handbook. Seattle, WA: Mountaineers Books.

Meteomont Service. 2017. Avalanche Bulletin. Historical archive. http://www.meteomont.gov.it/infoMeteo/. Accessed 23 Sept 2020 (in Italian).

Rapin, F. 2002. A new scale for avalanche intensity In Proceedings of the International Snow Science Workshop 2002, 29 September-4 October 2002, Penticton, B.C., Canada, 90-96.
Rapin, F., and C. Ancey. 2000. Occurrence conditions of two catastrophic avalanches at Chamonix, France. In Proceedings of the International Snow Science Workshop 2000, 2-6 October 2000, Big Sky, Montana, USA, 509-513.

Schweizer, J., B. Jamieson, and M. Schneebeli. 2003. Snow avalanche formation. Reviews of Geophysics 41(4): 1016-1041.

SLF (Institut für Schnee- und Lawinenforschung). 1999. New calculation methods in the mapping of avalanche risks (Neue Berechnungsmethoden in der Lawinengefahrenkartierung). Technical report. Davos, Switzerland: Institut für Schnee- und Lawinenforschung (in German).

Teich, M., J.T. Fischer, T. Feistl, P. Bebi, M. Christen, and A. GrêtRegamey. 2014. Computational snow avalanche simulation in forested terrain. Natural Hazards and Earth System Sciences 14(5): 2233-2248.

Vera Valero, C., K.W. Jones, Y. Bühler, and P. Bartelt. 2015. Release temperature, snow-cover entrainment and the thermal flow regime of snow avalanches. Cold Regions Science and Technology 61(225): 173-184.

Vera Valero, C., N. Wever, M. Christen, and P. Bartelt. 2018. Modeling the influence of snow cover temperature and water content on wet-snow avalanche runout. Natural Hazards and Earth System Sciences 18(3): 869-887. 